\title{
Sensitivity of formaldehyde (HCHO) column measurements from a geostationary satellite to temporal variation of the air mass factor in East Asia
}

\author{
Hyeong-Ahn Kwon ${ }^{1}$, Rokjin J. Park ${ }^{1}$, Jaein I. Jeong ${ }^{1}$, Seungun Lee ${ }^{1}$, Gonzalo González Abad ${ }^{2}$, Thomas P. Kurosu ${ }^{3}$, \\ Paul I. Palmer ${ }^{4}$, and Kelly Chance ${ }^{2}$ \\ ${ }^{1}$ School of Earth and Environmental Sciences, Seoul National University, Seoul, Republic of Korea \\ ${ }^{2}$ Atomic and Molecular Physics Division, Harvard-Smithsonian Center for Astrophysics, Cambridge, \\ Massachusetts, USA \\ ${ }^{3}$ Earth Science, Jet Propulsion Laboratory, Pasadena, California, USA \\ ${ }^{4}$ National Centre for Earth Observation, School of GeoSciences, University of Edinburgh, Edinburgh, UK \\ Correspondence to: Rokjin J. Park (rjpark@snu.ac.kr)
}

Received: 8 August 2016 - Discussion started: 5 October 2016

Revised: 8 March 2017 - Accepted: 14 March 2017 - Published: 10 April 2017

\begin{abstract}
We examine upcoming geostationary satellite observations of formaldehyde (HCHO) vertical column densities (VCDs) in East Asia and the retrieval sensitivity to the temporal variation of air mass factors (AMFs) considering the presence of aerosols. Observation system simulation experiments (OSSE) were conducted using a combination of a global 3-D chemical transport model (GEOS-Chem), a radiative transfer model (VLIDORT), and a HCHO retrieval algorithm developed for the Geostationary Environment Monitoring Spectrometer (GEMS), which will be launched in 2019. Application of the retrieval algorithm to simulated hourly radiances yields the retrieved HCHO VCDs, which are then compared with the GEOS-Chem HCHO VCDs as true values for the evaluation of the retrieval algorithm. In order to examine the retrieval sensitivity to the temporal variation of AMF, we examine three $\mathrm{AMF}$ specifications, $\mathrm{AMF}_{\mathrm{m}}, \mathrm{AMF}_{\mathrm{h}}$, and $\mathrm{AMF}_{\mathrm{mh}}$, using monthly, hourly, and monthly mean hourly input data for their calculation, respectively. We compare the retrieved HCHO VCDs using those three AMFs and find that the $\mathrm{HCHO}$ VCDs with $\mathrm{AMF}_{\mathrm{h}}$ are in better agreement with the true values than the results using $\mathrm{AMF}_{\mathrm{mh}}$ and $\mathrm{AMF}_{\mathrm{m}}$. $\mathrm{AMF}_{\mathrm{mh}}$ reflects diurnal variation of planetary boundary layer and other meteorological parameters, so that the results with $\mathrm{AMF}_{\mathrm{mh}}$ show a better performance than those with $\mathrm{AMF}_{\mathrm{m}}$. The differences between $\mathrm{AMF}_{\mathrm{h}}$ and $\mathrm{AMF}_{\mathrm{m}}$ range from -0.76 to 0.74 in absolute value and are mainly caused by temporal changes in aerosol chemical compositions and
\end{abstract}

aerosol vertical distributions, which result in -27 to 58 and -34 to $43 \%$ changes in HCHO VCDs over China, respectively, compared to $\mathrm{HCHO}$ VCDs using $\mathrm{AMF}_{\mathrm{m}}$. We apply our calculated AMF table together with OMI aerosol optical properties to OMI HCHO products in March 2006, when Asian dust storms occurred, and find -32 to $47 \%$ changes in the retrieved $\mathrm{HCHO}$ columns due to temporal changes in aerosol optical properties in East Asia. The impact of aerosol temporal variability cannot be neglected for future geostationary observations.

\section{Introduction}

Formaldehyde (HCHO) is mainly produced by the oxidation of hydrocarbons with minor direct emissions from fuel combustion, vegetation, and biomass burning (DiGangi et al., 2012). Because of its short atmospheric lifetime $(\sim 1.5 \mathrm{~h})$ (De Smedt et al., 2008), HCHO vertical columns from satellite measurements have effectively been used to provide constraints on its precursor emissions, especially for biogenic isoprene emissions (Palmer et al., 2003; Abbot et al., 2003; Shim et al., 2005; Fu et al., 2007; Marais et al., 2012), the oxidation of which is the largest natural source of $\mathrm{HCHO}$ globally. Zhu et al. (2014) also used temporal oversampling of satellite observed $\mathrm{HCHO}$ columns to provide information 
for anthropogenic non-methane volatile organic compound (NMVOC) emissions in eastern Texas.

In East Asia, anthropogenic emissions have dramatically increased owing to the rapid economic growth over the recent decades (Jeong and Park, 2013). Satellite observed HCHO columns show an increasing trend in most East Asian countries, implying the increase in hydrocarbon emissions (De Smedt et al., 2010). On the other hand, Stavrakou et al. (2014) used top-down isoprene emissions constrained by satellite observations to show the decreasing trend of inferred isoprene emissions in China since 2007, caused by decrease in annual temperatures. However, quantification of precursor emissions and their change is extremely challenging and provides large uncertainty in present air quality models in East Asia (Fu et al., 2007). Constraints based on observations, including satellite $\mathrm{HCHO}$ columns, are thus necessary to better quantify the emission of NMVOCs and its effects on air quality and climate in East Asia.

Column measurements of HCHO from space started in 1995 with the launch of the GOME instrument onboard ERS-2 (Chance et al., 2000). Since then, successive instruments, including SCIAMACHY (Wittrock et al., 2006), OMI (Kurosu et al., 2004; González Abad et al., 2015), GOME-2 (De Smedt et al., 2012), and OMPS (Li et al., 2015; González Abad et al., 2016), onboard sun-synchronous satellites have observed global HCHO column concentrations with re-visiting between 1 and 6 days. Their minimum ground pixel sizes have been reduced from $40 \times 320 \mathrm{~km}^{2}$ (GOME) to $13 \times 24 \mathrm{~km}^{2}$ (OMI). Accordingly, HCHO global observations have increased in use to provide observational constraints on biogenic NMVOCs emissions over the United States (Abbot et al., 2003; Palmer et al., 2003, 2006), Europe (Dufour et al., 2009), Asia (Fu et al., 2007; Stavrakou et al., 2014), and other regions (Barkley et al., 2013; Marais et al., 2012), despite measurements from sun-synchronous satellites having limited observation frequency of at most once or twice a day to once a week for regions of interest. For anthropogenic emissions, the use of satellite observations for constraining anthropogenic emission is relatively limited because of lower anthropogenic $\mathrm{HCHO}$ concentration relative to biogenic HCHO (Zhu et al., 2014).

In order to overcome the limitations of sun-synchronous satellites and monitor air quality changes with higher temporal frequency over East Asia, the Korean Ministry of Environment will launch a geostationary satellite (GEOKOMPSAT 2B) carrying the Geostationary Environment Monitoring Spectrometer (GEMS) in 2019. GEMS has a spatial resolution of $7 \times 8 \mathrm{~km}^{2}$ over Seoul, Korea, and can measure trace gases and aerosols every hour during the daytime (at least eight times a day). Frequent observations on a finer spatial resolution provide more data with less cloud contamination compared to those of the sun-synchronous satellites. The Sentinel-4 (Ingmann et al., 2012) and Tropospheric Emissions Monitoring of Pollution (TEMPO) missions (Zoogman et al., 2016) for environmental geostation- ary satellites in Europe and North America, respectively, are also in preparation. GEMS monitors air quality changes over East Asia and has a role, along with Sentinel-4 and TEMPO, in monitoring intercontinental transport of trace gases and aerosols from source to receptor regions.

Satellite HCHO column observations are sensitive to the changes in the atmospheric conditions. In particular, the air mass factor (AMF), which is required to convert slant column densities (SCDs) to vertical column densities (VCDs), depends on cloud properties, vertical profiles of HCHO, surface reflectance, aerosols, and observation geometry (solar and viewing zenith angles) (Palmer et al., 2001; Martin et al., 2002; Lee et al., 2009). Gonzi et al. (2011) examined the sensitivity of AMF to the injection height and optical properties of aerosols for biomass burning emission constraints using HCHO satellite measurements. Leitão et al. (2010) examined the aerosol effect on AMF calculation for satellite $\mathrm{NO}_{2}$ observations.

For sun-synchronous satellites, pre-calculated AMFs determined by monthly averaged $\mathrm{HCHO}$ and aerosol vertical profiles have been applied for computational efficiency (De Smedt et al., 2008; González Abad et al., 2015). With geostationary satellites, however, we are interested in monitoring the diurnal variation of trace gases and aerosols for which atmospheric conditions can change over the measurement period.

Here we examine the necessity of temporal AMF for geostationary satellite observations. We analyze the retrieval sensitivity to AMF calculated with different temporal variations of input parameters such as aerosol optical properties and vertical distributions of $\mathrm{HCHO}$ and aerosol. We quantify retrieval errors given different temporal resolution of $\mathrm{AMF}$ values by comparing the retrieved versus true HCHO VCDs in observation system simulation experiments (OSSE).

\section{Observation system simulation experiments (OSSE)}

We conduct the OSSE as illustrated in Fig. 1, using a global 3-D chemical transport model (GEOS-Chem) (Bey et al., 2001), the Vector Linearized Discrete Ordinate Radiative Transfer (VLIDORT) model (Spurr, 2006), and a retrieval algorithm developed for GEMS in this study (Chance et al., 2000; González Abad et al., 2015). Detailed information on GEOS-Chem and VLIDORT can be found in the aforementioned references. Here we briefly discuss our application.

We first perform a global simulation to obtain spatial and temporal distributions of gas and aerosol species using GEOS-Chem v9-01-02. The model is driven by Modern-Era Retrospective Analysis for Research and Applications (MERRA) and the Goddard Earth Observing System (GEOS-5) reanalysis meteorological data for years 2006 and 2009, respectively. GEOS-Chem has a $2^{\circ} \times 2.5^{\circ}$ (latitude $\times$ longitude) spatial resolution and 47 levels from the surface to $0.01 \mathrm{hPa}$. Biogenic emission of isoprene is com- 


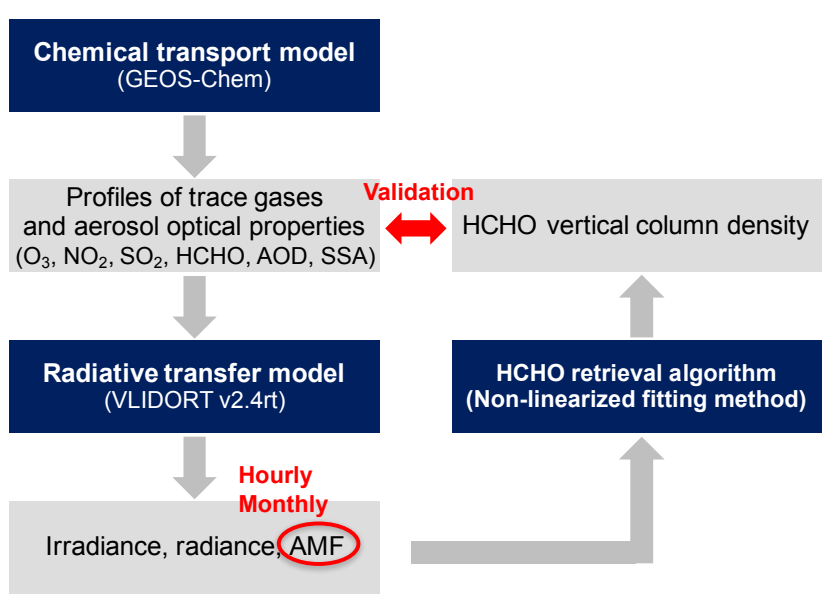

Figure 1. Schematic diagram of observation system simulation experiments (OSSE) used to validate our retrieval algorithm and to examine its sensitivity to the temporal variation of AMF values. GEOS-Chem, driven by assimilated meteorological data, is used to produce profiles of atmospheric constituent concentrations. VLIDORT calculates observed radiances measured by geostationary satellites using atmospheric constituent concentrations and meteorological conditions from GEOS-Chem simulations. The HCHO retrieval algorithm is developed based on least-squares fitting of a non-linearized Lambert-Beer model and is validated by comparisons between simulated and retrieved column densities of HCHO. The latter are obtained by applying the retrieval algorithm to the observed radiances from VLIDORT. Details are provided in the text.

puted using the Model of Emissions of Gases and Aerosols from Nature (MEGAN) version 2.1 (Guenther et al., 2006). Anthropogenic emissions are taken from the Emissions Database for Global Atmospheric Research (EDGAR) version 2.0 inventory (Olivier et al., 1996) for the globe in a mosaic fashion with the Intercontinental Chemical Transport Experiment Phase B (INTEX-B) inventory developed by Zhang et al. (2009) for Asia. We use monthly biomass burning emissions from the Global Fire Emissions Database (GFED) version 3 inventory (van der Werf et al., 2010).

All the simulated concentrations of gases and aerosols are archived every hour for the East Asia domain (70$150^{\circ} \mathrm{E}, 4^{\circ} \mathrm{S}-54^{\circ} \mathrm{N}$ ) and are provided as input for other model calculations. For example, aerosol optical properties, which are important input for radiative transfer model simulations below, are calculated using Flexible Aerosol Optical Depth (FlexAOD) with the simulated aerosol concentrations including sulfate-nitrate-ammonium, organic carbon, black carbon, sea salt, and dust aerosols (Hess et al., 1998; Mishchenko et al., 1999; Sinyuk et al., 2003). Hourly aerosol optical depth (AOD), single scattering albedo (SSA), and asymmetry factor are also archived over the domain for use in radiative transfer calculations.

We then conduct a radiative transfer model simulation using VLIDORT driven by the simulated profiles of gases and aerosol optical properties described above as well as meteo- rological data. We calculate radiances at the top of the atmosphere. The calculated radiances in the $300-500 \mathrm{~nm}$ spectral range of GEMS with a $0.2 \mathrm{~nm}$ spectral sampling are assumed as synthetic radiances to simulate GEMS measurements and are referred to as "observed radiances" henceforth. We use the observed radiances to evaluate the retrieval algorithm and to examine its sensitivity to several parameters. However, the observed radiances do not include any noise terms such as polarization errors and temperature errors of sensors and are not convoluted with a slit function since it is not available yet. The evaluation of our retrieval algorithm sensitivity and the impact of AMFs on $\mathrm{HCHO}$ retrievals we derive below have therefore to be considered a "best-case scenario". The radiative transfer simulation accounts for the extinction of aerosols and gases including $\mathrm{O}_{3}, \mathrm{NO}_{2}, \mathrm{SO}_{2}$, and $\mathrm{HCHO}$. Aerosol optical properties at 300, 400,600, and $999 \mathrm{~nm}$ are used in the simulation. VLIDORT also yields derivatives of radiances with respect to optical thicknesses of interfering gases that are used to calculate AMFs.

Finally, we apply our retrieval algorithm to the observed radiances to obtain the satellite observed HCHO columns. This retrieval process begins by fitting a simple LambertBeer model that explains the absorption of trace gases and the scattering by molecules in the atmosphere to the observed radiances by using a non-linear least square method (Chance et al., 2000).

$\mathrm{HCHO}$ absorption is so weak that the accuracy of retrievals is very sensitive to the fitting window selection (Hewson et al., 2013). The HCHO absorption bands overlap the $\mathrm{O}_{3}$ absorption bands, which are the strongest interference in the HCHO retrieval, so the fitting window must be selected to minimize the impact of the strong $\mathrm{O}_{3}$ absorption region. Instruments such as GOME, SCIAMACHY, OMI, and GOME-2 have used slightly different fitting windows. In this study, we select $327.5-358.0 \mathrm{~nm}$ for the fitting window of the $\mathrm{HCHO}$ retrieval. In the retrieval algorithm, we consider the Ring effect (Chance and Spurr, 1997), $\mathrm{O}_{3}$ absorption cross sections at 228 and $273 \mathrm{~K}$ (Daumont et al., 1992; Malicet et al., 1995), $\mathrm{NO}_{2}$ absorption cross sections at $220 \mathrm{~K}$ (Vandaele et al., 1998), $\mathrm{SO}_{2}$ absorption cross sections at $298 \mathrm{~K}$ (Hermans et al., 2009; Vandaele et al., 2009), and HCHO absorption cross sections at $300 \mathrm{~K}$ (Chance and Orphal, 2011).

For the retrieval of SCDs of target species from sunsynchronous satellite measurements, the differential optical absorption spectroscopy (DOAS) method has frequently been used with a linearized equation of the logarithm of the Lambert-Beer model divided by the solar irradiance $\left(I_{0}\right)(\mathrm{De}$ Smedt et al., 2008). In this study, we apply the fitting method developed by Chance et al. (2000) that uses the LambertBeer model in its original, non-linearized form.

SCDs from radiance fitting are converted to vertical amounts considering the path of solar radiance and viewing geometry of satellites. An AMF is a correction factor of the path length of light from an SCD to a VCD, including the varying sensitivity of the observations at different altitudes. 
It is defined as the ratio of the SCD to the VCD. Palmer et al. (2001) derived a simple formulation of an AMF, including scattering and absorption of gases with the vertical integration of a function multiplying scattering weights and vertical shape factors. The decoupling of the scattering weights and vertical shape factors has the advantage of allowing the calculation of them separately using a radiative transfer model and a chemical transport model, respectively. We conduct AMF calculations in VLIDORT simulations using Eq. (1) from Palmer et al. (2001) with hourly trace gas profiles including $\mathrm{HCHO}$ and aerosol profiles from GEOS-Chem.

$\mathrm{AMF}=-\frac{1}{\int_{0}^{\mathrm{TOA}} k_{\lambda} \rho \mathrm{d} z} \int_{0}^{\tau_{\mathrm{v}}} \frac{\partial \ln I}{\partial \tau} \mathrm{d} \tau$,

where $k_{\lambda}$ indicates the absorption cross section $\left(\mathrm{cm}^{2}\right.$ molecule $\left.{ }^{-1}\right)$ at each wavelength, $\rho$ is a number density (molecules $\mathrm{cm}^{-3}$ ), TOA stands for top of the atmosphere, $\tau$ and $\tau_{\mathrm{v}}$ are an optical thickness and that of the vertical column, respectively, and $I$ is a radiance. We use AMF values at $346 \mathrm{~nm}$, which is in the middle of the $\mathrm{HCHO}$ fitting window.

\section{Evaluation of the $\mathrm{HCHO}$ retrieval algorithm}

In this section, we evaluate the HCHO retrieval algorithm developed for GEMS using the OSSE discussed in Sect. 2. The simulated data, including trace gas $\left(\mathrm{O}_{3}, \mathrm{NO}_{2}, \mathrm{SO}_{2}\right.$, and $\mathrm{HCHO}$ ) concentrations, meteorological data, and aerosol optical properties and profiles for March, June, September, and December 2006, are used to calculate radiances in the OSSE as explained above. In radiance calculations, solar zenith angles are used at 11:00 local standard time (LST) of Seoul on the equinoxes and solstices (21 of each month), and viewing zenith angles are calculated based on GEMS orbit at $\sim 36000 \mathrm{~km}$ altitude above $\sim 128.2^{\circ} \mathrm{E}$ longitude at the Equator. We assume a Lambertian surface reflectance of 0.05 . As mentioned above, the simulated radiances do not include noise and errors. SCDs retrieved by radiance fitting are converted to VCDs using AMFs with and without aerosols.

Figure 2 presents GEOS-Chem HCHO VCDs in East Asia (first column) used in the OSSE to compute the observed radiances. The highest GEOS-Chem HCHO columns occur in Southeast Asia, including the Indo-China Peninsula and Indonesia, mainly driven by large biomass burning emissions whose seasonal variations differ slightly depending on the regions. Values in the Indo-China Peninsula $\left(92-105^{\circ} \mathrm{E}, 12-25^{\circ} \mathrm{N}\right)$ are highest in March-May, which is a typical dry season. In Indonesia $\left(100-118^{\circ} \mathrm{E}, 2^{\circ} \mathrm{S}-\right.$ $4^{\circ} \mathrm{N}$ ), $\mathrm{HCHO}$ columns are generally high throughout the whole year because of the biogenic emissions in tropical forests. In 2006, a strong El Niño occurred and resulted in massive fire events in Borneo and Sumatra for SeptemberOctober (Stavrakou et al., 2009), which led to enhancements of HCHO columns of up to $4.3 \times 10^{16}$ molecules $\mathrm{cm}^{-2}$ in
September. On the other hand, seasonal variability at midlatitudes $\left(>25^{\circ} \mathrm{N}\right)$ follows those of biogenic activity. For example, HCHO VCDs in China $\left(105-120^{\circ} \mathrm{E}, 25-40^{\circ} \mathrm{N}\right)$ increase to $1.3 \times 10^{16}$ molecules $\mathrm{cm}^{-2}$ in June and September but decrease to $4.6 \times 10^{15}$ and $3.7 \times 10^{16}$ molecules $\mathrm{cm}^{-2}$ in March and December, respectively.

Retrieved HCHO VCDs are also presented in Fig. 2. Most HCHO VCDs for previous sun-synchronous satellites including OMI and GOME-2 have been retrieved without the explicit consideration of aerosol effects on AMFs because aerosols are implicitly accounted for from satellite cloud products, which are coupled with the presence of aerosols (De Smedt et al., 2008; González Abad et al., 2015). In order to avoid complexity and to understand the retrieval sensitivity to the presence of aerosols in East Asia, we only focus on clear sky conditions and compare a retrieval using AMFs with aerosols to that using AMFs without aerosols. Retrieved HCHO VCDs accounting for aerosols (second column in Fig. 2) show spatial and seasonal patterns similar to GEOS-Chem values. Coefficients of determination $\left(R^{2}\right)$ between the retrieved and simulated HCHO VCDs for each month are 0.98 or higher, with regression slopes close to one $(0.95-1.01)$ except for winter $\left(R^{2}=0.95\right.$, slope $\left.=1.05\right)$. This is due to the limited capability of our algorithm at high solar zenith angles and low HCHO concentrations. For the calculation of regression coefficients, we exclude grids over $88.4^{\circ}$ solar zenith angle in winter (upper left corner in the domain) due to the high bias arising from high solar and viewing zenith angles.

Results retrieved using no aerosols (third column in Fig. 2) also show a similar spatial and seasonal variation but with a high bias with respect to the values retrieved using aerosols and GEOS-Chem. We find that differences (HCHO VCDs with aerosols - HCHO VCDs without aerosols) are generally negative over China and India. The presence of aerosols in AMFs appears to result in the decreases in $\mathrm{HCHO}$ columns of up to $20 \%$ in regions where aerosol concentrations are high, such as China, India, and biomass burning areas. In biogenic emission regions, AOD at $300 \mathrm{~nm}$ is low $(<0.1)$ and thus its effect on AMFs is relatively minor, except for biomass burning cases occurring over Indonesia $\left(100-120^{\circ} \mathrm{E}, 4^{\circ} \mathrm{S}-\right.$ $\left.5^{\circ} \mathrm{N}\right)$ in September and Indo-China $\left(100-120^{\circ} \mathrm{E}, 10-20^{\circ} \mathrm{N}\right)$ in March. HCHO VCDs are also increased by $14 \%$ due to aerosols in regions with high solar and viewing zenith angles.

In radiance fitting, the averaged root mean square (rms) error of fitting residuals is $3.3 \times 10^{-4}$, and the averaged HCHO slant column error is $1.9 \times 10^{15}$ molecules $\mathrm{cm}^{-2}$. Both are relatively small, indicating a successful retrieval because no additional errors are included in the observed radiances. Our retrieved values should be considered as the best-case retrievals that we can obtain from the satellite observations. More detailed error analysis is beyond the scope of this study and will be conducted as soon as the GEMS instrument parameters are available. We generally find that fitting rms er- 

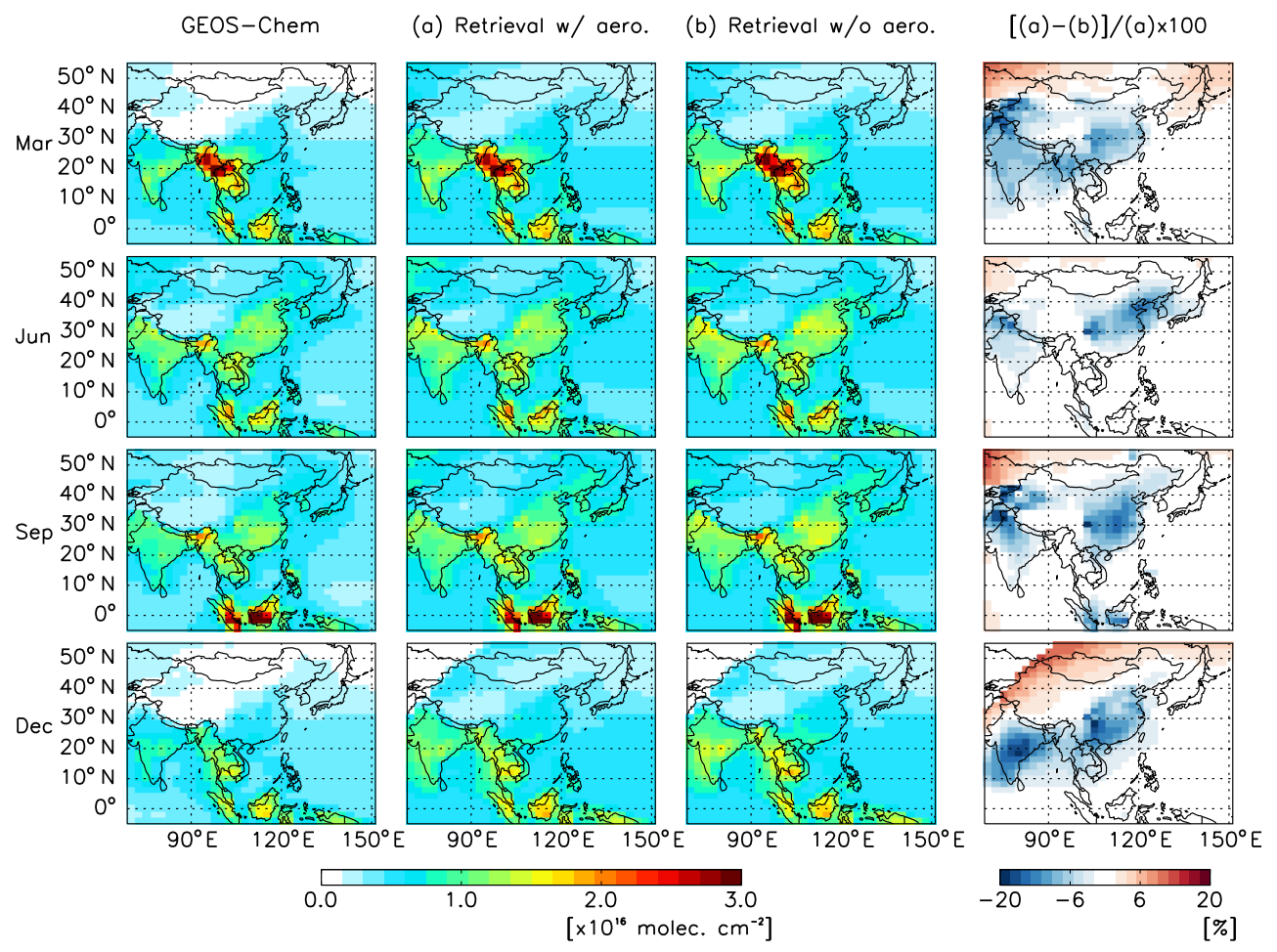

Figure 2. HCHO vertical column densities (VCDs) simulated from GEOS-Chem (first column) and retrieved HCHO VCDs using AMFs with aerosols (second column) and without aerosols (third column) for a month of each season in 2006. Relative differences between the two retrievals using AMFs with and without aerosols are shown in the fourth column representing the aerosol effect on the retrieved HCHO VCDs.

rors and HCHO slant column errors tend to depend on solar and viewing zenith angles so that these errors gradually increase in regions further away from the position of sun and satellite. HCHO slant column errors also depend on HCHO concentration in the atmosphere, and uncertainties decrease to $8.1 \times 10^{14}$ molecules $\mathrm{cm}^{-2}$ in regions with intense wildfires in March when HCHO concentrations are very high.

\section{Sensitivity of the HCHO retrieval to AMF temporal specifications}

Aerosol concentrations in East Asia are high because of natural and anthropogenic contributions. They include soil dust aerosols from deserts and arid regions prevelant in spring, black carbon and organic aerosols from biomass burning, and inorganic sulfate-nitrate-ammonium (SNA) aerosols from industrial activities caused by rapid economic development (Eck et al., 2005; Jethva et al. 2014). In particular, natural aerosols such as dust and biomass burning aerosols are transported to the free troposphere by mechanisms such as frontal passages or thermally driven convection associated with their formation processes. Aerosol layers over the polluted boundary layer can play a role in modulating incoming and backscattered radiance and thus cause an error in the retrieved quantities of satellite measurements. In order to correct this error, we need to consider the effect of aerosols on measured radiances. In this section, we investigate different effects of aerosols when measuring $\mathrm{HCHO}$ columns from GEMS by including aerosols in AMF calculations. We further examine the retrieval sensitivity with respect to temporal variation of aerosol optical properties, aerosol profiles, and $\mathrm{HCHO}$ profiles.

We use the OSSE described in Sect. 2 to examine AMF temporal variations and their impact on $\mathrm{HCHO}$ retrievals. For geostationary satellites, temporal changes in atmospheric conditions can affect AMF calculations. Here, we use three AMF specifications associated with the temporal variation of input data for AMF calculations. Input data include $\mathrm{HCHO}$ profiles, aerosol optical properties and profiles, temperatures, pressures, and other interfering gases $\left(\mathrm{O}_{3}, \mathrm{NO}_{2}\right.$, and $\left.\mathrm{SO}_{2}\right)$ from GEOS-Chem simulations. We use monthly, hourly, and monthly-averaged hourly input data at each model grid to compute $\mathrm{AMF}_{\mathrm{m}}, \mathrm{AMF}_{\mathrm{h}}$, and $\mathrm{AMF}_{\mathrm{mh}}$, respectively, for June 2009. First of all, all three AMFs vary hourly as functions of the solar zenith angle and location. However, at a given solar zenith angle and location, $\mathrm{AMF}_{\mathrm{m}}$ does not change due to use of a monthly mean input dataset over all times of all days in a given month, $\mathrm{AMF}_{\mathrm{h}}$ changes every hour within a month, and $\mathrm{AMF}_{\mathrm{mh}}$ changes hourly with no day-to-day vari- 
09:00 LST

(a)

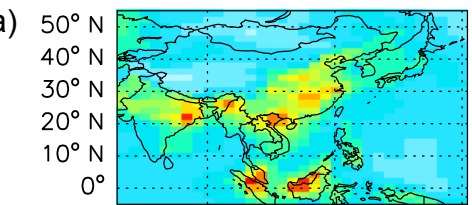

(b)

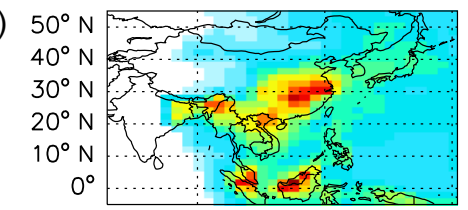

(c)

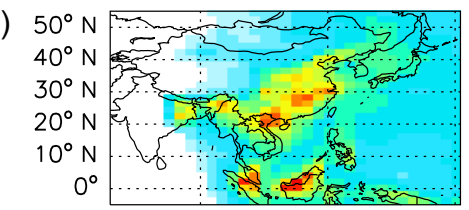

(d)

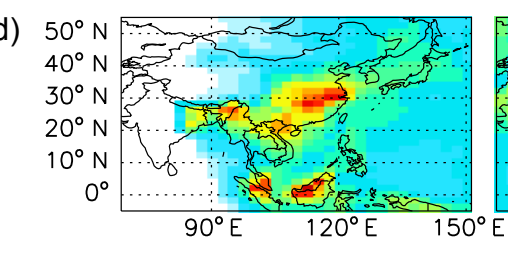

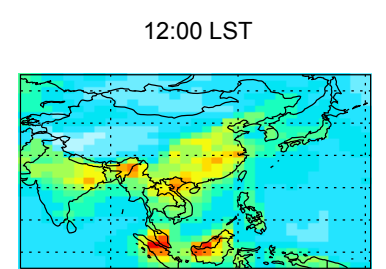
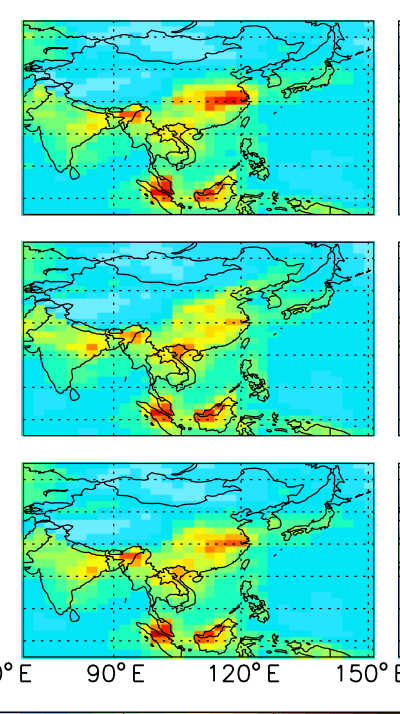
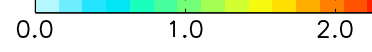

$3.0 \quad\left[\times 10^{16}\right.$ molec. $\left.\mathrm{cm}^{-2}\right]$
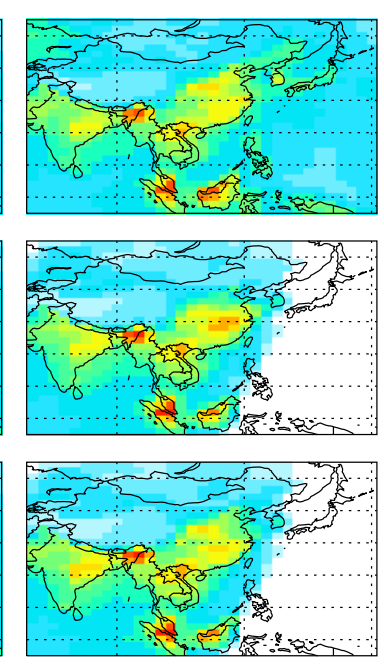

Figure 3. (a) HCHO VCDs simulated by GEOS-Chem at 09:00, 12:00, and 18:00 local standard time (LST) of Seoul on 21 June 2009. (b) Retrieved HCHO VCDs with $\mathrm{AMF}_{\mathrm{m}}$. (c) Retrieved HCHO VCDs with $\mathrm{AMF}_{\mathrm{h}}$. (d) Retrieved HCHO VCDs with $\mathrm{AMF}_{\mathrm{mh}}$.

ation. Then, we apply $\mathrm{AMF}_{\mathrm{m}}, \mathrm{AMF}_{\mathrm{h}}$, and $\mathrm{AMF}_{\mathrm{mh}}$ to derived HCHO SCDs in order to obtain retrieved HCHO VCDs.

Figure 3 compares HCHO VCDs simulated by GEOSChem and retrieved VCDs with three AMF specifications at $346 \mathrm{~nm}$ at 09:00, 12:00, and 18:00 LST in Seoul on 21 June 2009. We take the model results as true values in the comparison with the retrieved HCHO VCDs. Figure 3 shows that GEOS-Chem simulation has large HCHO VCDs of $1.2 \times 10^{16}$ molecules $\mathrm{cm}^{-2}$ over Indonesia near the Equator, reflecting large biogenic emissions from tropical forests. Enhanced HCHO VCDs as high as $9.6 \times 10^{15}$ molecules $\mathrm{cm}^{-2}$ over the northern Indo-China Peninsula and China (100$120^{\circ} \mathrm{E}, 20-35^{\circ} \mathrm{N}$ ) result from biogenic and anthropogenic emissions. We find that the retrieved HCHO VCDs with three AMF specifications are generally consistent with the model results, reproducing spatial distributions of HCHO VCDs. However, HCHO VCDs retrieved with $\mathrm{AMF}_{\mathrm{h}}$ show better agreement with GEOS-Chem than those retrieved using $\mathrm{AMF}_{\mathrm{m}}$ and $\mathrm{AMF}_{\mathrm{mh}}$, especially over China. Retrieved $\mathrm{HCHO}$ columns using $\mathrm{AMF}_{\mathrm{m}}$ and $\mathrm{AMF}_{\mathrm{mh}}$ are biased high compared to the true values and those using $\mathrm{AMF}_{\mathrm{h}}$ over China.

Figure 4 shows scatterplot comparisons of retrieved VCDs versus model simulations at 09:00, 12:00, and 18:00 LST of Seoul over China $\left(105-120^{\circ} \mathrm{E}, 15-45^{\circ} \mathrm{N}\right)$. We find some biases in the retrieved products using $\mathrm{AMF}_{\mathrm{m}}$ and $\mathrm{AMF}_{\mathrm{mh}}$ com- pared with the true values and the results with $\mathrm{AMF}_{\mathrm{h}}$. Regression slopes are close to one for the results using $\mathrm{AMF}_{\mathrm{h}}$ (0.96-1.08) but higher than one for the results using $\mathrm{AMF}_{\mathrm{m}}$ (1.14-1.31) and $\mathrm{AMF}_{\mathrm{mh}}$ (1.08-1.24). The coefficients of determination $\left(R^{2}\right)$ between the retrieved versus true VCDs differ significantly and are $0.73,0.83$, and 0.99 for the retrieved VCDs with $\mathrm{AMF}_{\mathrm{m}}, \mathrm{AMF}_{\mathrm{mh}}$, and $\mathrm{AMF}_{\mathrm{h}}$ at 12:00 LST, respectively, indicating the best performance of the retrieval using $\mathrm{AMF}_{\mathrm{h}}$ relative to those with the other AMFs.

We find that both the regression slope and $R^{2}$ for the results using $\mathrm{AMF}_{\mathrm{mh}}$ suggest a better performance than those with $\mathrm{AMF}_{\mathrm{m}}$, particularly at 12:00 LST, but do not show any significant improvement at 9 and 18:00 LST. We infer from this that the temporal variability of species, caused by the diurnal variation of the planetary boundary layer (PBL), mostly explains the difference between the retrievals using $\mathrm{AMF}_{\mathrm{m}}$ and $\mathrm{AMF}_{\mathrm{mh}}$. Accounting for this diurnal variability appears to be important for the retrieval when the PBL is fully developed and the active chemical processes typically occur. Therefore, we think that the use of $\mathrm{AMF}_{\mathrm{mh}}$ could be an alternative and more efficient way to improve HCHO VCD retrievals for geostationary satellites, with less computation required relative to the use of $\mathrm{AMF}_{\mathrm{h}}$.

The discrepancy between retrieved products over China is caused by temporal variation of $\mathrm{HCHO}$ vertical profiles 

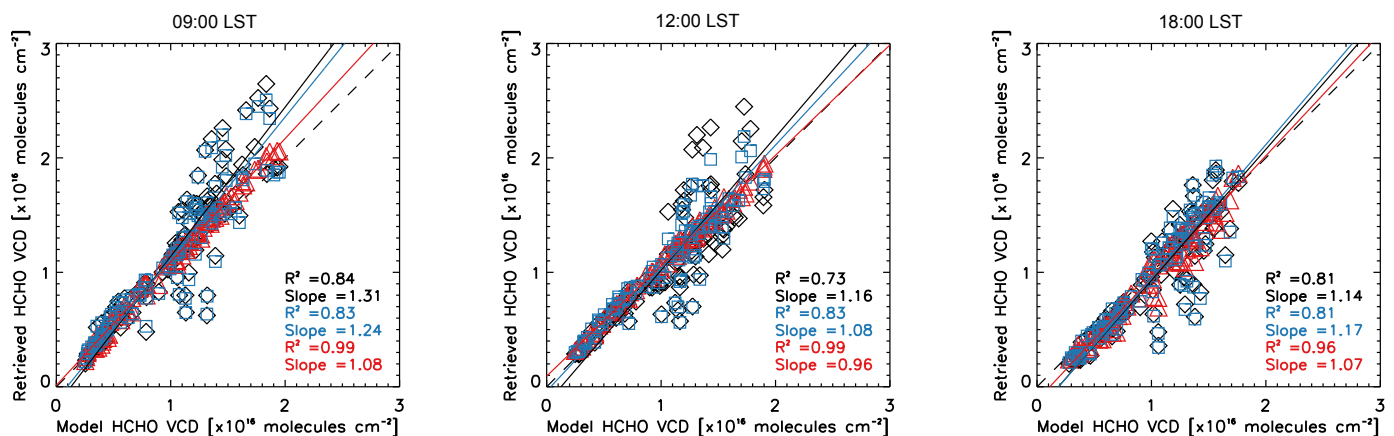

Figure 4. Comparison of the retrieved versus simulated VCDs shown in Fig. 3 over China $\left(105-120^{\circ}\right.$ E, $\left.15-45^{\circ} \mathrm{N}\right)$. Black diamonds, red triangles, and blue squares denote the retrieved $\mathrm{VCD}_{\mathrm{s}}$ using $\mathrm{AMF}_{\mathrm{m}}, \mathrm{AMF}_{\mathrm{h}}$, and $\mathrm{AMF}_{\mathrm{mh}}$, respectively. Statistics are shown as insets.
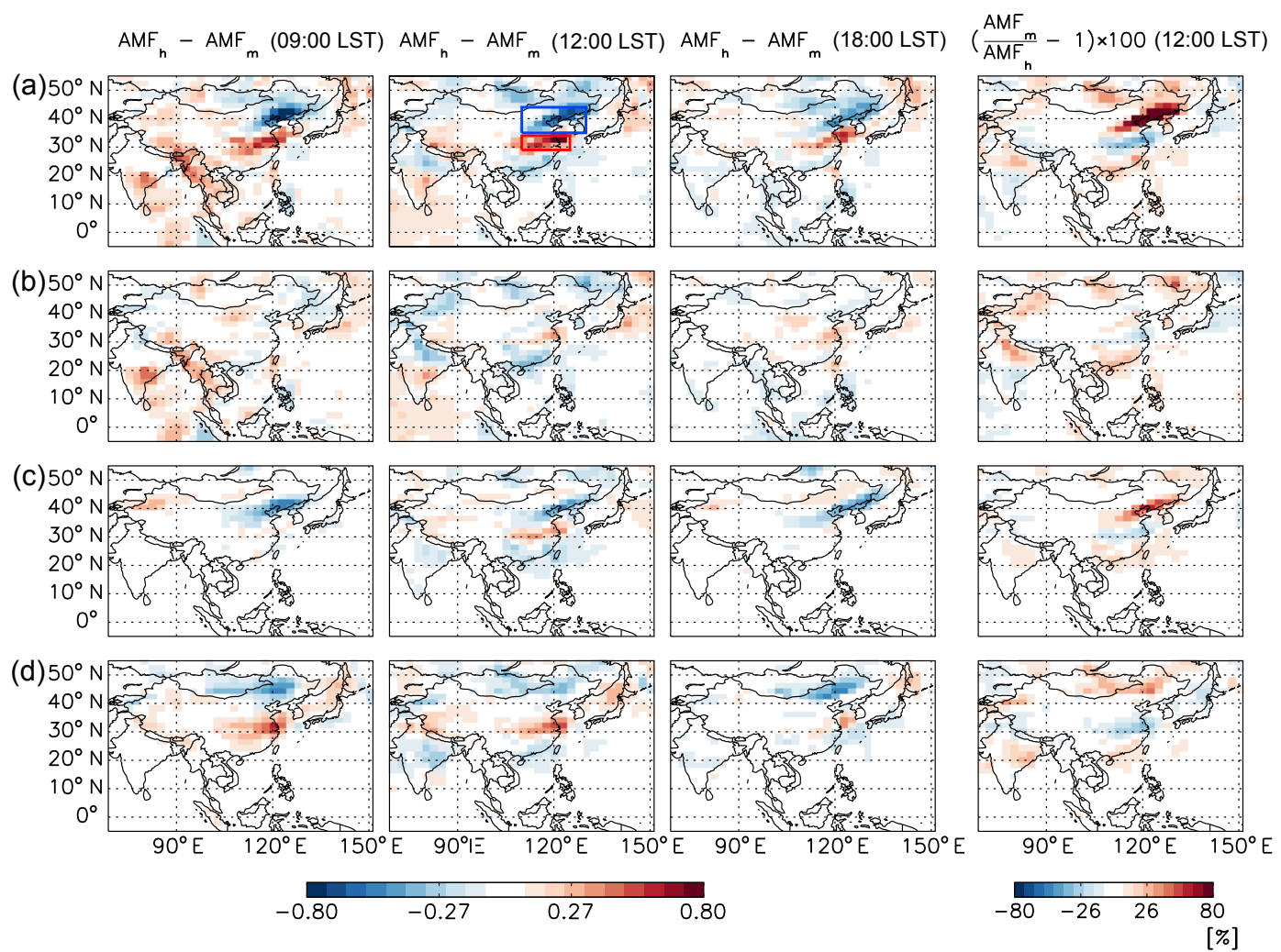

Figure 5. (a) Differences between $\mathrm{AMF}_{\mathrm{h}}$ and $\mathrm{AMF}_{\mathrm{m}}$ values and relative contributions to them by the temporal changes in (b) $\mathrm{HCHO}$ profiles, (c) aerosol optical properties, and (d) aerosol vertical distributions. The first to third columns are results at 09:00, 12:00, and 18:00 LST at Seoul on 21 June 2009. The fourth column gives percentage differences for the ratio of $\mathrm{AMF}_{\mathrm{m}}$ to $\mathrm{AMF}_{\mathrm{h}}$ indicating changes in $\mathrm{HCHO} \mathrm{VCDs}$ with $\mathrm{AMF}_{\mathrm{h}}$ relative to those with $\mathrm{AMF}_{\mathrm{m}}$ at 12:00 LST. Blue and red boxes denote regions of shielding and enhancement effects.

and aerosols. Figure 5 shows the difference between $\mathrm{AMF}_{\mathrm{h}}$ and $\mathrm{AMF}_{\mathrm{m}}$ and individual contributions of $\mathrm{HCHO}$ profiles, aerosol optical properties (AOD and SSA), and aerosol profiles to the difference at 09:00, 12:00, and 18:00 LST of Seoul on 21 June 2009.

First of all, we find that $\mathrm{AMF}_{\mathrm{h}}$ at 09:00, 12:00, and 18:00 LST is smaller by $0.76,0.71$, and 0.52 in absolute value than $\mathrm{AMF}_{\mathrm{m}}$ over northeastern China (blue box of Fig. 5a), respectively. On the other hand, the former at each time is higher by up to $0.59,0.74$, and 0.62 relative to the latter in the middle of eastern China (red box of Fig. 5a).

In order to quantify individual contributions to AMF differences between the two, each of the HCHO profiles, aerosol optical properties, and aerosol vertical distributions is allowed to vary hourly, while other variables are kept fixed using monthly averaged data for AMF calculation. We find that $\mathrm{HCHO}$ profile variations affect AMF over the entire domain, ranging from -0.48 to 0.45 in absolute value (Fig. $5 b$ ). 
In the morning (09:00 LST), the effect of HCHO profile variation is dominant over India and the Indo-China Peninsula, where $\mathrm{AMF}_{\mathrm{h}}$ is higher than $\mathrm{AMF}_{\mathrm{m}}$, reflecting that hourly $\mathrm{HCHO}$ is distributed at higher altitudes relative to its monthly mean profiles and thus absorbs more photons. At 12:00 LST, this effect disappears over Indo-China and remains over India. AMF changes caused by temporal variation of $\mathrm{HCHO}$ profiles are relatively small in the evening (18:00 LST).

More pronounced differences shown over China appear to correlate significantly with the effect of aerosols, whose optical properties (Fig. 5c) and vertical distributions (Fig. 5d) change with time, resulting in AMF variations of -0.56 to 0.40 and -0.50 to 0.57 , respectively. In Fig. $5 \mathrm{c}$, the aerosol optical property effects occurring in eastern China with high aerosol loadings show a different sign in that the decrease occurs in the north, whereas the increase is in the south, especially at 12:00 LST. This contrast corresponds to the hourly increases in absorbing and scattering aerosols relative to their monthly mean values in the north and south, respectively. In particular, the decrease in AMFs in the north results from decreased $\mathrm{HCHO}$ absorption within and below aerosol layers (a shielding effect) as incoming photons cannot penetrate effectively aerosol layers and reach near the surface due to aerosol absorption (Leitão et al., 2010).

We also find that aerosol profile variation is important for the AMF calculation as well as aerosol optical properties (Fig. 5d). That is evident, in particular, over the middle of eastern China, where the increment of AMF occurs. The resulting change in AMF is due to $\mathrm{HCHO}$ above aerosol layers. $\mathrm{HCHO}$ absorptions increase within and above aerosol layers because of an increased photon path length caused by additional aerosol scattering effects, which is referred to as an enhancement (albedo) effect (Chimot et al., 2016). Chimot et al. (2016) suggested the enhancement effect associated with the relative vertical distribution between an absorbing gas and aerosol.

In order to examine the factors for a shielding effect $\left(\mathrm{AMF}_{\mathrm{h}}<\mathrm{AMF}_{\mathrm{m}}\right)$ and an enhancement effect $\left(\mathrm{AMF}_{\mathrm{h}}>\mathrm{AMF}_{\mathrm{m}}\right)$ as shown in blue and red boxes in Fig. 5a, we plot mean profiles of aerosol and HCHO averaged over the two boxes as shown in Fig. 6. First of all, we find that aerosol profiles considerably differ between monthly and hourly values, especially for its peak height, whereas relatively insignificant changes exist for $\mathrm{HCHO}$ profiles. The shielding effect appears to be associated with the aerosol layer higher than that of HCHO (Fig. 6a) and the enhancement effect is due to the opposite vertical distributions of the two (Fig. 6b), which is consistent with the previous studies by Leitão et al. (2010) and Chimot et al. (2016).

Our analysis further reveals the importance of aerosol optical properties, especially for the shielding effect shown in the blue box of Fig. 5a. If the relative vertical distributions of aerosol and HCHO is a single crucial factor for the shielding effect, we should expect a similar magnitude of $\mathrm{AMF}_{\mathrm{h}}$
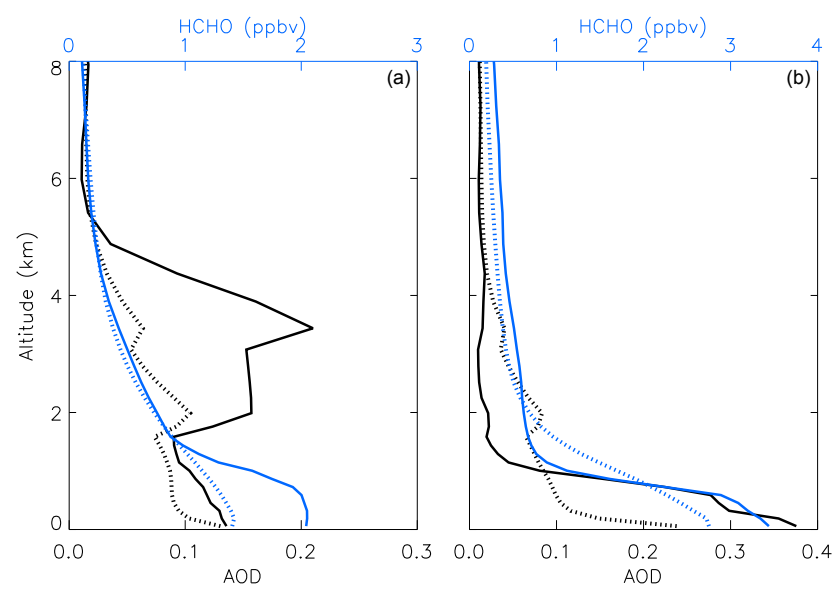

Figure 6. (a) Mean profiles of AOD (black) and HCHO (blue) over a region with decreased $\mathrm{AMF}_{\mathrm{h}}$ relative to $\mathrm{AMF}_{\mathrm{m}}$ (blue box in Fig. 5a). (b) Same as in (a) but for values over a region with increased $\mathrm{AMF}_{\mathrm{h}}$ relative to $\mathrm{AMF}_{\mathrm{m}}$ (red box in Fig. 5a). Solid and dotted lines denote hourly and monthly values, respectively.

decreases relative to $\mathrm{AMF}_{\mathrm{m}}$ for the $\mathrm{AMF}$ sensitivity test to aerosol vertical distributions (Fig. 5d). In the sensitivity test, we used the same vertical profiles of aerosol (black solid) and HCHO (blue dotted) shown in Fig. 6a, but the resulting changes in $\mathrm{AMF}_{\mathrm{h}}$ in Fig. $5 \mathrm{~d}$ are much smaller relative to the values shown in Fig. $5 \mathrm{c}$ from the sensitivity test to aerosol optical properties. This is because the sensitivity results shown in Fig. 5d were obtained using the monthly mean aerosol SSA $(=0.95)$, which is higher than hourly aerosol SSA $(=0.87)$. In other words, the shielding effect is more pronounced with an absorbing aerosol layer rather than a scattering aerosol layer aloft, which might diminish the shielding effect by increasing a photon path length within or below the aerosol layer by the multiple light scattering (Dickerson et al., 1997).

In order to further understand the factors for the spatial pattern of AMF changes, we compare hourly AOD and SSA at $300 \mathrm{~nm}$ with monthly mean values at 12:00 LST for Seoul (Fig. 7). In general, the region, where hourly AOD is larger than monthly mean AOD, corresponds to the region with the significant change in AMF. We find that hourly SSA is lower in northeastern China (blue box of Fig. 5a) and a bit higher in the middle of eastern China (red box of Fig. 5a) than monthly mean SSA. Absorbing aerosols in northeastern China result in the decrease in AMFs, whereas scattering aerosols in the middle of eastern China cause the increase in AMF at 12:00 LST. These spatial patterns of SSA and thus AMF changes are mainly determined by scattering inorganic SNA aerosols in the south and slightly absorbing dust aerosols in the north as shown in Fig. 7c and d, respectively.

We also calculate percentage differences for the ratio of $\mathrm{AMF}_{\mathrm{m}}$ to $\mathrm{AMF}_{\mathrm{h}}$ at 12:00 LST (fourth column in Fig. 5), which indicates changes in $\mathrm{HCHO}$ VCDs with $\mathrm{AMF}_{\mathrm{h}}$ rel- 
(a) $A O D_{h}-A O D_{m}$

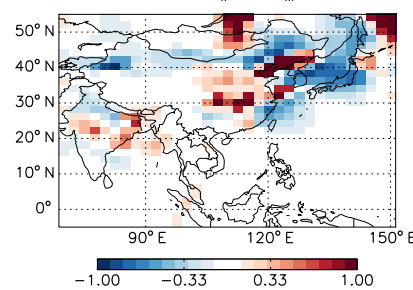

(c) AOD of SNA

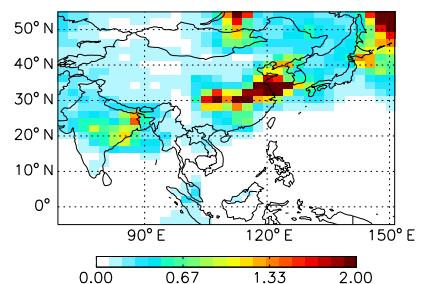

(b) $S S A_{n}-S S A_{m}$

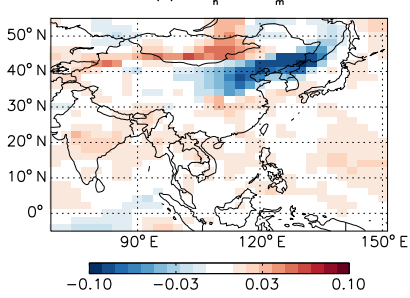

(d) AOD of dust

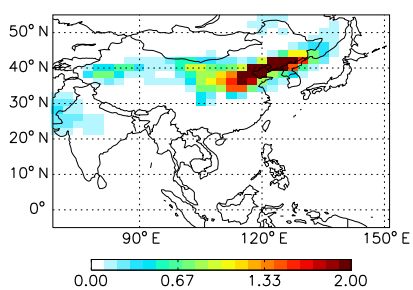

(a) Ratio of AMF to AMF

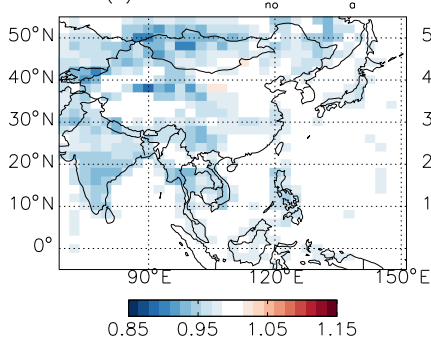

(b) Monthly mean of AMF - AMF

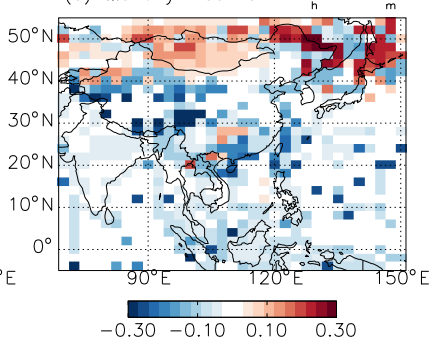

Figure 9. (a) Ratio of AMFs without aerosols $\left(\mathrm{AMF}_{\text {no }}\right)$ to $\mathrm{AMFs}$ with aerosols $\left(\mathrm{AMF}_{\mathrm{a}}\right)$. (b) Differences of the monthly mean of $A M F_{h}$ versus $A M F_{m} . A M F_{h}$ denotes a value using AOD and SSA at each measurement time, and $\mathrm{AMF}_{\mathrm{m}}$ is a value using monthly mean AOD and SSA. Aerosol optical properties used in the calculation are from OMI observations (OMAERUV) for March 2006.

monthly averaged parameters may cause considerable errors for geostationary satellite measurements such as GEMS in East Asia. To improve HCHO GEMS retrievals AMF calculations have to consider the diurnal variability of aerosols and their chemical composition.

Actual GEMS measurements will contain noise from polarization, temperature fluctuations of the GEMS instrument, stray light, and other sources, which will reduce retrieval sensitivity. However, despite this expected reduction in retrieval sensitivity, the main results on the impact of aerosols from this study will not change fundamentally. In the next section, we demonstrate these effects on the real-life example of the OMI HCHO retrievals.

\section{Effects of aerosols on OMI HCHO products}

Previous AMF applications to convert SCDs to VCDs of OMI HCHO are based on a look-up table approach with no explicit consideration of aerosols (González Abad et al., 2015). Here, we apply AMF values with an explicit consideration of aerosols to OMI HCHO SCDs to examine the effect of aerosol presence and its temporal variation in clear sky conditions (cloud fraction $<0.05$ ) on the retrieved $\mathrm{HCHO}$ VCDs focusing on East Asia in 2006. The cloud fraction included in OMI HCHO products is used, which is provided from OMCLDO2 products (Stammes et al., 2008). The AMF calculation has been conducted similarly with monthly mean data from the GEOS-Chem simulations for 2006. In order to apply efficiently our values to the OMI SCDs we compute an AMF look-up table as a function of longitude, latitude, AODs $(0.1,0.5,1.0,1.5$, and 2.0), SSAs (0.82, 0.87, 0.92, and 0.97$)$, solar zenith angles $\left(5,30,60\right.$, and $\left.80^{\circ}\right)$, and viewing zenith angles $\left(0,10,20,30,40,50,60,70\right.$, and $\left.80^{\circ}\right)$. An aerosol layer height is also important to determine AMF as discussed in Sect. 4. However, the information is not yet available from the satellites with ultraviolet and visible channels. Thus, aerosol layer heights are not an explicit input pa- 

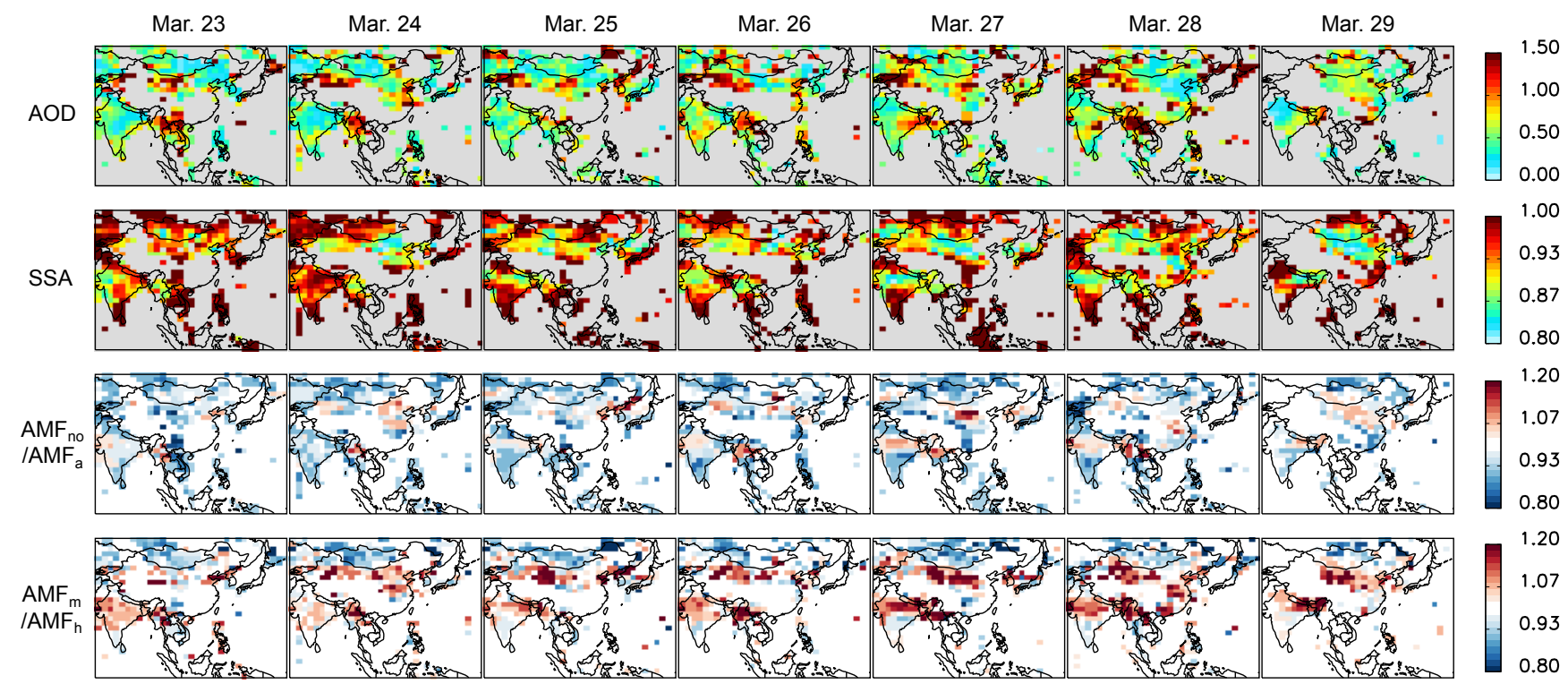

Figure 10. Values of AOD, SSA, aerosol optical property effects on $A M F s\left(A M F_{n o} / A_{M F}\right)$, and temporal effects of aerosol optical properties on $A M F s\left(A M F_{m} / A_{M} F_{h}\right)$ for 23-29 March 2006, when a strong dust event occurred in East Asia. $\mathrm{AMF}_{\text {no }}$ and $\mathrm{AMF}_{\mathrm{a}}$ indicate values without and with aerosols, respectively. $\mathrm{AMF}_{\mathrm{m}}$ is a value using monthly mean $\mathrm{AOD}$ and SSA from OMI. AMF $\mathrm{h}_{\mathrm{h}}$ is a value using AOD and SSA from OMI at each measurement time.

rameter of our AMF look-up table, as AMF values are based on monthly averaged aerosol profiles given by the GEOSChem simulation.

Figure 8 shows monthly averaged AOD and SSA at $354 \mathrm{~nm}$ (cloud fraction<0.05) from OMI UV radiances (OMAERUV) for March 2006. High AOD extending from the Taklamakan Desert with a relatively low SSA indicates slightly absorbing dust aerosols in East Asia. OMAERUV products are derived from measured reflectance from OMI and climatological surface albedo from TOMS at 354 and $388 \mathrm{~nm}$, aerosol type, and aerosol layer height (Torres et al., 2013). Ahn et al. (2014) evaluated AOD from OMAERUV with Aerosol Robotic Network (AERONET) data, deriving a root mean square error of 0.16 and a correlation coefficient of 0.81 at 44 global sites over 4 years (2005-2008). SSA from OMAERUV shows a difference of $\pm 0.03( \pm 0.05)$ compared to that of AERONET at $47 \%$ (69\%) of 269 sites (Jethva et al., 2014). Although Torres et al. (2013) excluded pixels with cloud contamination using scene reflectivity and surface reflectance at $388 \mathrm{~nm}$, aerosol index, and aerosol type, we use pixels where cloud fraction is less than 0.05 . This allows us to analyze explicit aerosol effects on AMF calculation without having to worry about cloud contamination.

We calculate scene-dependent AMFs by using the OMI aerosol products together with our AMF look-up table. Figure 9a shows the ratio of AMFs without aerosols $\left(\mathrm{AMF}_{\mathrm{no}}\right)$ to $A M F s$ with aerosols $\left(\mathrm{AMF}_{\mathrm{a}}\right) . \mathrm{AMF}_{\mathrm{a}}$ at each measurement time are calculated by using AOD and SSA from OMI. The ratio is mostly less than one, reflecting the decrement of $\mathrm{HCHO}$ VCDs using $\mathrm{AMF}_{\mathrm{a}}$ by $11 \%$ in comparison with those using $\mathrm{AMF}_{\text {no. }}$.

In order to examine aerosol temporal variation effects on AMF calculation, we use the same AMF specifications discussed in Sect. 4. In the section, $\mathrm{AMF}_{\mathrm{h}}$ denotes AMFs using aerosol optical properties at each measurement time, and $\mathrm{AMF}_{\mathrm{m}}$ is AMFs using monthly mean AOD and SSA. Figure $9 \mathrm{~b}$ represents differences between monthly mean $\mathrm{AMF}_{\mathrm{h}}$ and $\mathrm{AMF}_{\mathrm{m}}$, which reflect the non-linear response of the AMF calculation due to aerosol temporal variation. Negative values are generally seen south of $40^{\circ} \mathrm{N}$, indicating that monthly mean $\mathrm{AMF}_{\mathrm{h}}$ is lower than $\mathrm{AMF}_{\mathrm{m}}$, so that $\mathrm{HCHO}$ column concentrations using $\mathrm{AMF}_{\mathrm{h}}$ are higher than those with $\mathrm{AMF}_{\mathrm{m}}$. The opposite sign occurs north of $40^{\circ} \mathrm{N}$ and in some parts of China.

Finally, we examine a dust storm event on 2329 March 2006 in order to explore an episodic case with very high aerosol concentrations. AOD and SSA (first and second rows in Fig. 10) are high and relatively low, respectively, corresponding to dust aerosols transported from the Taklamakan and Gobi deserts. The ratio of $\mathrm{AMF}_{\text {no }}$ to $\mathrm{AMF}_{\mathrm{a}}$ is less than one over most regions but higher than one over regions with dust aerosols (high AOD and relatively low SSA). The decreased $\mathrm{AMF}_{\mathrm{a}}$ relative to $\mathrm{AMF}_{\mathrm{no}}$ is a consequence of shielding effects caused by the absorbing dust aerosols. The effects are pronounced over central and northeastern China and are sometimes extended to downwind regions of Korea and the East Sea between Korea and Japan on 25 and 27 March. The ratio also increases due to biomass burning in the Indo-China Peninsula. The ratio indicates the change 
in $\mathrm{HCHO}$ VCDs which are in inverse proportion to AMFs. Therefore, the aerosol effects on AMFs make HCHO VCDs increased by $32 \%$ due to absorbing aerosols and decreased by $25 \%$ due to scattering aerosols compared to those using AMFs without aerosols.

Here we illustrate that the temporal variation effects of AOD and SSA on the AMF calculation (fourth row in Fig. 10) can adequately be accounted for using satellite observations, especially for episodic events such as dust storms and biomass burning. $\mathrm{AMF}_{\mathrm{m}}$ uses OMI monthly mean AOD and SSA for March 2006, and $\mathrm{AMF}_{\mathrm{h}}$ uses them at each measurement time. The ratio of $\mathrm{AMF}_{\mathrm{m}}$ to $\mathrm{AMF}_{\mathrm{h}}$ ranges from 0.68 to 1.47 , reflecting $\mathrm{HCHO}$ changes of -32 to $47 \%$ by using $\mathrm{AMF}_{\mathrm{h}}$ compared to $\mathrm{VCDs}$ with $\mathrm{AMF}_{\mathrm{m}}$. That indicates that aerosol optical properties simultaneously measured for geostationary satellites can be used to calculate AMF for $\mathrm{HCHO}$ VCDs and to reduce the associated uncertainty with the retrieved products.

We only consider AOD and SSA in the AMF calculation, although an aerosol layer height affects AMF calculation, which is not readily available from OMI yet. However, Park et al. (2016) recently showed a possibility to retrieve aerosol height information using $\mathrm{O}_{2}-\mathrm{O}_{2}$ collision from GEMS measurements. For GEMS, we could use the retrieved aerosol information to compute scene-dependent AMFs, which will be used to improve the gas-species retrieval at each measurement time.

\section{Summary}

We examined the sensitivity of retrieved HCHO VCDs to AMF temporal specifications. We computed $\mathrm{AMF}_{\mathrm{m}}, \mathrm{AMF}_{\mathrm{h}}$, and $\mathrm{AMF}_{\mathrm{mh}}$, using monthly, hourly, and monthly mean hourly input data for their calculation, and compared retrieved HCHO VCDs with true values in the OSSE. Retrieved VCDs with three AMF specifications were consistent with the true values, but the result using $\mathrm{AMF}_{\mathrm{h}}$ showed the best agreement with the true values. The differences between $\mathrm{HCHO}$ VCDs with $\mathrm{AMF}_{\mathrm{h}}$ and $\mathrm{AMF}_{\mathrm{m}}$ over China were caused by the temporal changes in aerosol chemical compositions and aerosol profiles in our AMF calculation. Relative to $\mathrm{HCHO}$ VCDs with $\mathrm{AMF}_{\mathrm{m}}$, the first effect resulted in -27 to $58 \%$ changes in HCHO VCDs, whereas the latter effect caused -34 to $43 \%$ changes in China. In addition, compared to the result with $\mathrm{AMF}_{\mathrm{m}}$, the use of $\mathrm{AMF}_{\mathrm{mh}}$ showed a better agreement with the true values, which indicates that accounting for diurnal variation is an important factor for the retrievals in times with fully developed PBL and active chemistry. We suggest the use of $\mathrm{AMF}_{\mathrm{mh}}$ as an alternative and more efficient way to improve HCHO VCD retrievals for geostationary satellites, with less computation required relative to the use of $\mathrm{AMF}_{\mathrm{h}}$.

We also applied our AMF look-up table accounting for the presence of aerosols to OMI HCHO SCDs in order to examine explicit effects of aerosol and its temporal change on OMI retrieval, primarily focusing on clear sky conditions (cloud fraction $<0.05$ ). We found that the consideration of aerosol optical properties resulted in a decrease in $\mathrm{HCHO}$ VCDs by $11 \%$ on a monthly mean basis. In a dust storm event for 23-29 March 2006, the consideration of aerosols for AMF calculation changed HCHO VCDs from -25 to $32 \%$ relative to $\mathrm{HCHO}$ VCDs, with no explicit aerosol effects. In addition, AMFs using OMI aerosol products at each measurement time changed HCHO VCDs from -32 to $47 \%$ compared to those with AMFs using monthly mean AOD and SSA from OMI. Our test with the OMI products indicated a possibility that simultaneously measured aerosol optical products can be used to calculate AMFs considering aerosol and its temporal variation effects to reduce the associated uncertainty of HCHO VCD retrievals.

In this study, we selected pixels in clear sky conditions to examine explicit aerosol effects on AMF calculation because the retrieval algorithms of aerosol and cloud interact with each other. We may need to investigate interaction effects between aerosol and cloud on AMFs when we consider cloud products from satellites to calculate AMFs.

Data availability. Products from OMI are available at https://disc. sci.gsfc.nasa.gov/Aura/data-holdings/OMI.

Competing interests. The authors declare that they have no conflict of interest.

Acknowledgements. We thank anonymous reviewers for invaluable comments. We thank Gabriele Curci for providing FlexAOD to calculate aerosol optical properties in this study (http://pumpkin.aquila.infn.it/flexaod). This work was supported by the GEMS Program of the Ministry of Environment, Korea and Eco Innovation Program of KEITI (ARQ201204015) and the Korea Ministry of Environment as the Climate Change Correspondence Program.

Edited by: M. Van Roozendael

Reviewed by: two anonymous referees

\section{References}

Abbot, D. S., Palmer, P. I., Martin, R. V., Chance, K. V., Jacob, D. J., and Guenther, A.: Seasonal and interannual variability of North American isoprene emissions as determined by formaldehyde column measurements from space, Geophys. Res. Lett., 30, 1886, doi:10.1029/2003GL017336, 2003.

Ahn, C., Torres, O., and Jethva, H.: Assessment of OMI near-UV aerosol optical depth over land, J. Geophys. Res.-Atmos., 119, 2457-2473, doi:10.1002/2013JD020188, 2014.

Barkley, M. P., De Smedt, I., Van Roozendael, M., Kurosu, T. P., Chance, K., Arneth, A., Hagberg, D., Guenther, A., Paulot, 
F., and Marais, E.: Top-down isoprene emissions over tropical South America inferred from SCIAMACHY and OMI formaldehyde columns, J. Geophys. Res.-Atmos., 118, 68496868, doi:10.1002/jgrd.50552, 2013.

Bey, I., Jacob, D. J., Yantosca, R. M., Logan, J. A., Field, B. D., Fiore, A. M., Li, Q., Liu, H. Y., Mickley, L. J., and Schultz, M. G.: Global modeling of tropospheric chemistry with assimilated meteorology: Model description and evaluation, J. Geophys. Res.-Atmos., 106, 23073-23095, 2001.

Chance, K. and Orphal, J.: Revised ultraviolet absorption cross sections of $\mathrm{H}_{2} \mathrm{CO}$ for the HITRAN database, J. Quant. Spectrosc. Ra., 112, 1509-1510, 2011.

Chance, K. and Spurr, R. J. D.: Ring effect studies: Rayleigh scattering, including molecular parameters for rotational Raman scattering, and the Fraunhofer spectrum, Appl. Optics, 36, 52245230, 1997.

Chance, K., Palmer, P. I., Spurr, R. J. D., Martin, R. V., Kurosu, T. P., and Jacob, D. J.: Satellite observations of formaldehyde over North America from GOME, Geophys. Res. Lett., 27, 34613464, 2000.

Chimot, J., Vlemmix, T., Veefkind, J. P., de Haan, J. F., and Levelt, P. F.: Impact of aerosols on the OMI tropospheric $\mathrm{NO}_{2}$ retrievals over industrialized regions: how accurate is the aerosol correction of cloud-free scenes via a simple cloud model?, Atmos. Meas. Tech., 9, 359-382, doi:10.5194/amt-9-359-2016, 2016.

Daumont, D., Brion, J., Charbonnier, J., and Malicet, J.: Ozone UV spectroscopy I: Absorption cross-sections at room temperature, J. Atmos. Chem., 15, 145-155, 1992.

De Smedt, I., Müller, J.-F., Stavrakou, T., van der A, R., Eskes, H., and Van Roozendael, M.: Twelve years of global observations of formaldehyde in the troposphere using GOME and SCIAMACHY sensors, Atmos. Chem. Phys., 8, 4947-4963, doi:10.5194/acp-8-4947-2008, 2008.

De Smedt, I., Stavrakou, T., Müller, J. F., van der A, R. J., and Van Roozendael, M.: Trend detection in satellite observations of formaldehyde tropospheric columns, Geophys. Res. Lett., 37, L18808, doi:10.1029/2010GL044245, 2010.

De Smedt, I., Van Roozendael, M., Stavrakou, T., Müller, J.-F., Lerot, C., Theys, N., Valks, P., Hao, N., and van der A, R.: Improved retrieval of global tropospheric formaldehyde columns from GOME-2/MetOp-A addressing noise reduction and instrumental degradation issues, Atmos. Meas. Tech., 5, 2933-2949, doi:10.5194/amt-5-2933-2012, 2012.

Dickerson, R. R., Kondragunta, S., Stenchikov, G., Civerolo, K. L., Doddridge, B. G., and Holben, B. N.: The Impact of Aerosols on Solar Ultraviolet Radiation and Photochemical Smog, Science, 278, 827-830, doi:10.1126/science.278.5339.827, 1997.

DiGangi, J. P., Henry, S. B., Kammrath, A., Boyle, E. S., Kaser, L., Schnitzhofer, R., Graus, M., Turnipseed, A., Park, J.-H., Weber, R. J., Hornbrook, R. S., Cantrell, C. A., Maudlin III, R. L., Kim, S., Nakashima, Y., Wolfe, G. M., Kajii, Y., Apel, E. C., Goldstein, A. H., Guenther, A., Karl, T., Hansel, A., and Keutsch, F. N.: Observations of glyoxal and formaldehyde as metrics for the anthropogenic impact on rural photochemistry, Atmos. Chem. Phys., 12, 9529-9543, doi:10.5194/acp-12-9529-2012, 2012.

Dufour, G., Wittrock, F., Camredon, M., Beekmann, M., Richter, A., Aumont, B., and Burrows, J. P.: SCIAMACHY formaldehyde observations: constraint for isoprene emission estimates over Eu- rope?, Atmos. Chem. Phys., 9, 1647-1664, doi:10.5194/acp-91647-2009, 2009.

Eck, T. F., Holben, B. N., Dubovik, O., Smirnov, A., Goloub, P., Chen, H. B., Chatenet, B., Gomes, L., Zhang, X. Y., Tsay, S. C., Ji, Q., Giles, D., and Slutsker, I.: Columnar aerosol optical properties at AERONET sites in central eastern Asia and aerosol transport to the tropical mid-Pacific, J. Geophys. Res.-Atmos., 110, D06202, doi:10.1029/2004JD005274, 2005.

Fu, T. M., Jacob, D. J., Palmer, P. I., Chance, K., Wang, Y. X., Barletta, B., Blake, D. R., Stanton, J. C., and Pilling, M. J.: Space-based formaldehyde measurements as constraints on volatile organic compound emissions in east and south Asia and implications for ozone, J. Geophys. Res., 112, D06312, doi:10.1029/2006JD007853, 2007.

González Abad, G., Liu, X., Chance, K., Wang, H., Kurosu, T. P., and Suleiman, R.: Updated Smithsonian Astrophysical Observatory Ozone Monitoring Instrument (SAO OMI) formaldehyde retrieval, Atmos. Meas. Tech., 8, 19-32, doi:10.5194/amt-8-192015, 2015.

González Abad, G., Vasilkov, A., Seftor, C., Liu, X., and Chance, K.: Smithsonian Astrophysical Observatory Ozone Mapping and Profiler Suite (SAO OMPS) formaldehyde retrieval, Atmos. Meas. Tech., 9, 2797-2812, doi:10.5194/amt-9-2797-2016, 2016.

Gonzi, S., Palmer, P. I., Barkley, M. P., De Smedt, I., and Van Roozendael, M.: Biomass burning emission estimates inferred from satellite column measurements of HCHO: Sensitivity to co-emitted aerosol and injection height, Geophys. Res. Lett., 38, L14807, doi:10.1029/2011GL047890, 2011.

Guenther, A., Karl, T., Harley, P., Wiedinmyer, C., Palmer, P. I., and Geron, C.: Estimates of global terrestrial isoprene emissions using MEGAN (Model of Emissions of Gases and Aerosols from Nature), Atmos. Chem. Phys., 6, 3181-3210, doi:10.5194/acp-63181-2006, 2006.

Hermans, C., Vandaele, A. C., and Fally, S.: Fourier transform measurements of $\mathrm{SO}_{2}$ absorption cross sections:: I. Temperature dependence in the $24000-29000 \mathrm{~cm}^{-1}(345-420 \mathrm{~nm})$ region, J. Quant. Spectrosc. Ra., 110, 756-765, 2009.

Hess, M., Koepke, P., and Schult, I.: Optical properties of aerosols and clouds: The software package OPAC, B. Am. Meteorol. Soc., 79, 831-844, 1998.

Hewson, W., Bösch, H., Barkley, M. P., and De Smedt, I.: Characterisation of GOME-2 formaldehyde retrieval sensitivity, Atmos. Meas. Tech., 6, 371-386, doi:10.5194/amt-6-371-2013, 2013.

Ingmann, P., Veihelmann, B., Langen, J., Lamarre, D., Stark, H., and Courrèges-Lacoste, G. B.: Requirements for the GMES atmosphere service and ESA's implementation concept: Sentinels-4/-5 and-5p, Remote Sens. Environ., 120, 58-69, doi:10.1016/j.rse.2012.01.023, 2012.

Jeong, J. I. and Park, R. J.: Effects of the meteorological variability on regional air quality in East Asia, Atmos. Environ., 69, 46-55, 2013.

Jethva, H., Torres, O., and Ahn, C.: Global assessment of OMI aerosol single-scattering albedo using ground-based AERONET inversion, J. Geophys. Res.-Atmos., 119, 9020-9040, 2014.

Kurosu, T. P., Chance, K., and Sioris, C. E.: Preliminary results for $\mathrm{HCHO}$ and $\mathrm{BrO}$ from the EOS-aura ozone monitoring instrument, Proc. SPIE Int. Soc. Opt. Eng., 5652, 116-123, 2004. 
Lee, C., Martin, R. V., van Donkelaar, A., O’Byrne, G., Krotkov, N., Richter, A., Huey, L. G., and Holloway, J. S.: Retrieval of vertical columns of sulfur dioxide from SCIAMACHY and OMI: Air mass factor algorithm development, validation, and error analysis, J. Geophys. Res., 114, D22303, doi:10.1029/2009JD012123, 2009.

Leitão, J., Richter, A., Vrekoussis, M., Kokhanovsky, A., Zhang, Q. J., Beekmann, M., and Burrows, J. P.: On the improvement of $\mathrm{NO}_{2}$ satellite retrievals - aerosol impact on the airmass factors, Atmos. Meas. Tech., 3, 475-493, doi:10.5194/amt-3-475-2010, 2010.

Li, C., Joiner, J., Krotkov, N. A., and Dunlap, L.: A new method for global retrievals of $\mathrm{HCHO}$ total columns from the Suomi National Polar-orbiting Partnership Ozone Mapping and Profiler Suite, Geophys. Res. Lett., 42, 2515-2522, 2015.

Malicet, J., Daumont, D., Charbonnier, J., Parisse, C., Chakir, A., and Brion, J.: Ozone UV spectroscopy. II. Absorption crosssections and temperature dependence, J. Atmos. Chem., 21, $263-$ 273,1995

Marais, E. A., Jacob, D. J., Kurosu, T. P., Chance, K., Murphy, J. G., Reeves, C., Mills, G., Casadio, S., Millet, D. B., Barkley, M. P., Paulot, F., and Mao, J.: Isoprene emissions in Africa inferred from OMI observations of formaldehyde columns, Atmos. Chem. Phys., 12, 6219-6235, doi:10.5194/acp-12-62192012, 2012.

Martin, R. V., Chance, K., Jacob, D. J., Kurosu, T. P., Spurr, R. J., Bucsela, E., Gleason, J. F., Palmer, P. I., Bey, I., and Fiore, A. M.: An improved retrieval of tropospheric nitrogen dioxide from GOME, J. Geophys. Res.-Atmos., 107, ACH 9-1-ACH 921, 2002.

Martin, R. V., Jacob, D. J., Chance, K., Kurosu, T. P., Palmer, P. I., and Evans, M. J.: Global inventory of nitrogen oxide emissions constrained by space-based observations of $\mathrm{NO}_{2}$ columns, J. Geophys. Res., 108, 4537, doi:10.1029/2003JD003453, 2003.

Mishchenko, M. I., Dlugach, J. M., Yanovitskij, E. G., and Zakharova, N. T.: Bidirectional reflectance of flat, optically thick particulate layers: an efficient radiative transfer solution and applications to snow and soil surfaces, J. Quant. Spectrosc. Ra., 63, 409-432, 1999.

Olivier, J. G. J., Bouwman, A., Berdowski, J., Veldt, C., Bloos, J., Visschedijk, A., Zandveld, P., and Haverlag, J.: Description of EDGAR Version 2.0: A set of global emission inventories of greenhouse gases and ozone-depleting substances for all anthropogenic and most natural sources on a per country basis and on 1 degree $\times 1$ degree grid, National Institute of Public Health and the Environment RIVM Rep. 771060002 and TNO-MEP Rep. R96/119, 1996

Palmer, P. I., Jacob, D. J., Fiore, A. M., and Martin, R. V.: Air mass factor formulation for spectroscopic measurements from satellites: Application to formaldehyde retrievals from the Global Ozone Monitoring Experiment, J. Geophys. Res., 106, 14539514550, 2001.

Palmer, P. I., Jacob, D. J., Fiore, A. M., Martin, R. V., Chance, K., and Kurosu, T. P.: Mapping isoprene emissions over North America using formaldehyde column observations from space, J. Geophys. Res, 108, 4180, doi:10.1029/2002JD002153, 2003.

Palmer, P. I., Abbot, D. S., Fu, T.-M., Jacob, D. J., Chance, K., Kurosu, T. P., Guenther, A., Wiedinmyer, C., Stanton, J. C., Pilling, M. J., Pressley, S. N., Lamb, B., and Sumner, A. L.:
Quantifying the seasonal and interannual variability of North American isoprene emissions using satellite observations of the formaldehyde column, J. Geophys. Res.-Atmos., 111, D12315, doi:10.1029/2005JD006689, doi:10.1029/2005JD006689, 2006.

Park, S. S., Kim, J., Lee, H., Torres, O., Lee, K.-M., and Lee, S. D.: Utilization of $\mathrm{O}_{4}$ slant column density to derive aerosol layer height from a space-borne UV-visible hyperspectral sensor: sensitivity and case study, Atmos. Chem. Phys., 16, 1987-2006, doi:10.5194/acp-16-1987-2016, 2016.

Shim, C., Wang, Y., Choi, Y., Palmer, P. I., Abbot, D. S., and Chance, K.: Constraining global isoprene emissions with Global Ozone Monitoring Experiment (GOME) formaldehyde column measurements, J. Geophys. Res.-Atmos., 110, D24301, doi:10.1029/2004JD005629, 2005.

Sinyuk, A., Torres, O., and Dubovik, O.: Combined use of satellite and surface observations to infer the imaginary part of refractive index of Saharan dust, Geophys. Res. Lett., 30, 1081, doi:10.1029/2002GL016189, 2003.

Spurr, R. J.: VLIDORT: A linearized pseudo-spherical vector discrete ordinate radiative transfer code for forward model and retrieval studies in multilayer multiple scattering media, J. Quant. Spectrosc. Ra., 102, 316-342, 2006.

Stammes, P., Sneep, M., de Haan, J. F., Veefkind, J. P., Wang, P., and Levelt, P. F.: Effective cloud fractions from the Ozone Monitoring Instrument: Theoretical framework and validation, J. Geophys. Res.-Atmos., 113, D16S38, doi:10.1029/2007JD008820, 2008.

Stavrakou, T., Müller, J.-F., De Smedt, I., Van Roozendael, M., van der Werf, G. R., Giglio, L., and Guenther, A.: Global emissions of non-methane hydrocarbons deduced from SCIAMACHY formaldehyde columns through 2003-2006, Atmos. Chem. Phys., 9, 3663-3679, doi:10.5194/acp-9-3663-2009, 2009.

Stavrakou, T., Müller, J.-F., Bauwens, M., De Smedt, I., Van Roozendael, M., Guenther, A., Wild, M., and Xia, X.: Isoprene emissions over Asia 1979-2012: impact of climate and land-use changes, Atmos. Chem. Phys., 14, 4587-4605, doi:10.5194/acp14-4587-2014, 2014.

Torres, O., Ahn, C., and Chen, Z.: Improvements to the OMI nearUV aerosol algorithm using A-train CALIOP and AIRS observations, Atmos. Meas. Tech., 6, 3257-3270, doi:10.5194/amt-63257-2013, 2013.

van der Werf, G. R., Randerson, J. T., Giglio, L., Collatz, G. J., Mu, M., Kasibhatla, P. S., Morton, D. C., DeFries, R. S., Jin, Y., and van Leeuwen, T. T.: Global fire emissions and the contribution of deforestation, savanna, forest, agricultural, and peat fires (19972009), Atmos. Chem. Phys., 10, 11707-11735, doi:10.5194/acp10-11707-2010, 2010.

Vandaele, A. C., Hermans, C., Simon, P. C., Carleer, M., Colin, R., Fally, S., Merienne, M.-F., Jenouvrier, A., and Coquart, B.: Measurements of the $\mathrm{NO}_{2}$ absorption cross-section from $42000 \mathrm{~cm}^{-1}$ to $10000 \mathrm{~cm}^{-1}(238-1000 \mathrm{~nm})$ at $220 \mathrm{~K}$ and 294 K, J. Quant. Spectrosc. Ra., 59, 171-184, 1998.

Vandaele, A. C., Hermans, C., and Fally, S.: Fourier transform measurements of $\mathrm{SO}_{2}$ absorption cross sections: II.: Temperature dependence in the $29000-44000 \mathrm{~cm}^{-1}(227-345 \mathrm{~nm})$ region, J. Quant. Spectrosc. Ra., 110, 2115-2126, 2009.

Wittrock, F., Richter, A., Oetjen, H., Burrows, J. P., Kanakidou, M., Myriokefalitakis, S., Volkamer, R., Beirle, S., Platt, U., and Wagner, T.: Simultaneous global observations of glyoxal and 
formaldehyde from space, Geophys. Res. Lett., 33, L16804, doi:10.1029/2006GL026310, 2006.

Zhang, Q., Streets, D. G., Carmichael, G. R., He, K. B., Huo, H., Kannari, A., Klimont, Z., Park, I. S., Reddy, S., Fu, J. S., Chen, D., Duan, L., Lei, Y., Wang, L. T., and Yao, Z. L.: Asian emissions in 2006 for the NASA INTEX-B mission, Atmos. Chem. Phys., 9, 5131-5153, doi:10.5194/acp-9-5131-2009, 2009.

Zhu, L., Jacob, D. J., Mickley, L. J., Marais, E. A., Cohan, D. S., Yoshida, Y., Ducan, B. N., González Abad, G., and Chance, K. V.: Anthropogenic emissions of highly reactive volatile organic compounds in eastern Texas inferred from oversampling of satellite (OMI) measurements of HCHO columns, Environ. Res. Lett., 9, 114004, doi:10.1088/1748-9326/9/11/114004, 2014.
Zoogman, P., Liu, X., Suleiman, R. M., Pennington, W. F., Flittner, D. E., Al-Saadi, J. A., Hilton, B. B., Nicks, D. K., Newchurch, M. J., Carr, J. L., Janz, S. J., Andraschko, M. R., Arola, A., Baker, B. D., Canova, B. P., Chan Miller, C., Cohen, R. C., Davis, J. E., Dussault, M. E., Edwards, D. P., Fishman, J., Ghulam, A., González Abad, G., Grutter, M., Herman, J. R., Houck, J., Jacob, D. J., Joiner, J., Kerridge, B. J., Kim, J., Krotkov, N. A., Lamsal, L., Li, C., Lindfors, A., Martin, R. V., McElroy, C. T., McLinden, C., Natraj, V., Neil, D. O., Nowlan, C. R., O’Sullivan, E. J., Palmer, P. I., Pierce, R. B., Pippin, M. R., Saiz-Lopez, A., Spurr, R. J. D., Szykman, J. J., Torres, O., Veefkind, J. P., Veihelmann, B., Wang, H., Wang, J., and Chance, K.: Tropospheric emissions: Monitoring of pollution (TEMPO), J. Quant. Spectrosc. Ra., 186, 17-39, doi:10.1016/j.jqsrt.2016.05.008, 2016. 